\title{
VARIASI PENUTUP LAHAN PASCA PENAMBANGAN PASIR BATU (SIRTU) SEBAGAI PEMBEDA SIFAT FISIK, KIMIA DAN BIOLOGI TANAH
}

\author{
Dwi Herniti ${ }^{1}$ \\ Dosen Teknik Pertambangan Institut Teknologi Yogyakarta \\ dwi.herniti@gmail.com \\ Primanda Kiky² \\ Dosen Teknik Pertambangan Institut Teknologi Yogyakarta
}

\begin{abstract}
ABSTRAK
Gangguan atau kerusakan yang sering terjadi pasca penambangan pasir dan batu (sirtu) adalah mengenai kondisi tanah, diantaranya penurunan produktivitas tanah, kesuburan tanah, jumlah mikroorganisme tanah dan daya serap/permeabilitas, dan lain sebagainya. Oleh karena itu diperlukan penelitian mengenai bagaimana variasi penutup lahan pasca penambangan pasir dan batu (sirtu) sebagai pembeda sifat fisik, kimia dan biologi tanah, dengan studi kasus di sebagian Wilayah Kabupaten Sleman, DIY.

Tujuan dari penelitian ini adalah untuk menganalisa pengaruh penambangan pasir terhadap sifat fisik, kimia dan biologi tanah pada variasi penutup lahan. Target khusus dari penelitian ini adalah sebagai dasar dalam melakukan konservasi tanah. Metode yang digunakan adalah metode survei dengan pengambilan sampel secara purposive sampling serta data statistik wilayah lokasi penelitian.Data yang digunakan adalah data primer untuk jenis struktur tanah dan data sekunder untuk analisis sifat fisik, kimia, dan biologi tanah.

Dari hasil pengamatan lapangan dan uji laboratorium diperoleh hasil analisis sifat fisik tanah dari sisi permeabilitas yang tidak menunjukkan perbedaan yang jelas pada setiap lapisan. Ini menunjukkan bahwa abu yang dilontarkan merapi dengan kadar air yang tinggi mampu meresap dan berpengaruh pada lapisan dibawahnya. Kata Kunci : Penambangan Pasir dan Batu, Sifat Tanah, Penutup Lahan
\end{abstract}

\section{(VARIATION OF LAND COVER IN SAND AND STONE POST- MINING AS DIFFERENTIATOR OF SOIL PHYSICAL, CHEMICAL AND BIOLOGICAL PROPERTIES)}

\begin{abstract}
Disturbance that often occurs after sand and rocks mining is related to soil conditions, including a decrease in soil productivity, soil fertility, number of soil microorganisms and absorption / permeability, and so on. Therefore, this research objective is to analyze variations in land cover in sand and stone post-mining as a differentiator of soil physical, chemical and biological properties, using a case study in Sleman Regency, DIY. The specific target of this research is as a basis for soil conservation. The data collection method is conducting purposive sampling of soil in the research location. The results will be tested using statistical tests using the F test on the characteristics of soil properties observed to find out whether there is a real influence or not from sand mining activities and after further testing (Duncan test) it can be known which locations give significant differences. The results shows that the permeability do not exhibit a clear distinction in each layer. This is an
\end{abstract}


indication that the soil and volcanic ash was found to have high permeability rate and can give influent to the layer below.

Keywords: Mining of Sand and Stone, Nature of Soil, Land Cover

\section{PENDAHULUAN}

\section{LATAR BELAKANG}

Potensi sumber daya alam di Indonesia yang sangat melimpah merupakan modal dasar pembangunan nasional dalam hal pengembangan wisata alam dan devisa negara dari sektor nonmigas yang harus dikelola, dikembangkan dan dimanfaatkan sebesar-besarnya dengan baik. Potensi sumber daya alam tersebut di harapkan dapat memberikan kemakmuran dan kesejahteraan secara berkelanjutan bagi rakyat melalui pola pemanfaatan sumber daya alam secara berkelanjutan yang mengacu pada upaya-upaya konservasi sebagai landasan dari proses tercapainya keseimbangan antara perlindungan, pengawetan, dan pemanfaatan dari sumber daya alam yang terbentang luas di Indonesia (Yudhistira, 2007).

Dampak negatif dari penambangan pasir dengan sistem penambangan terbuka ini terutama diakibatkan oleh degradasi lingkungan, perubahan geologi lingkungan antara lain kondisi estetika, topografi, kemiringan lereng, elevasi ketinggian, tersingkapnya batuan dasar, erosi, sedimentasi, kualitas dan kuantitas air tanah serta air permukaan, tata guna lahan, kestabilan batuan/ tanah, penurunan produktivitas tanah, kesuburan tanah, jumlah mikroorganisme tanah dan daya serap/permeabilitas; gangguan terhadap flora dan fauna; perubahan iklim mikro, serta berbagai permasalahan sosial.

Gangguan atau kerusakan yang sering terjadi pasca penambangan pasir adalah mengenai kondisi tanahnya, oleh karena itu diperlukan penelitian mengenai variasi penutup lahan pada kegiatan pasca penambangan pasir (sirtu) terhadap sifat fisik, kimia dan biologi tanah di sebagian Kabupaten Sleman DIY.

\section{PERMASALAHAN}

Pasir merupakan bahan galian golongan $\mathrm{C}$ yang memberikan dampak baik dampak positif dan negatif. Dampak positifnya salah satunya adalah meningkatnya pendapatan masyarakat lokal sekitar pertambangan, dan dampak negatifnya adalah terjadi kerusakan atau gangguan akibat penambangan pasir dan batu yaitu dampak langsung terhadap kondisi tanahnya. Oleh karena itu peneliti perlu melakukan penelitian mengenai kajian sifat fisik, kimia dan biologi tanah pasca penambangan pasir dan batu di sebagian wilayah Kabupaten Sleman DIY. 


\section{TUJUAN}

Tujuan dari penelitian pengaruh penambangan pasir dan batu (sirtu) terhadap sifat tanah di sekitar Sleman DIY ini adalah :

\section{Menganalisa pengaruh} penambangan pasir terhadap sifat fisik tanah pada variasi penutup lahan pasca penambangan pasir (sirtu)

2. Sebagai dasar untuk konservasi tanah.

\section{TINJAUAN PUSTAKA \\ 1. Penutup Lahan}

Penutup lahan adalah tutupan biofisik pada permukaan bumi yang dapat diamati merupakan suatu hasil pengaturan, aktifitas dan perlakuan manusia yang dilakukan pada jenis penutup lahan tertentu untuk melakukan aktifias produksi, perubahan ataupun perawatan pada penutup lahan tersebut (BSN, 2010).

Klasifikasi penutup lahan menurut Badan Standarisasi Nasional (2010) dibagi menjadi dua bagian besar yaitu daerah bervegetasi dan daerah tidak bervegetasi. Semua kelas penutup lahan dalam kategori daerah bervegetasi diturunkan dari pendekatan konseptual struktur fisiognomi yang konsisten dari bentuk tumbuhan, bentuk tutupan, tinggi tumbuhan, dan distribusi spasialnya. Sedangkan dalam kategori tidak bervegetasi, pendetailan kelas mengacu pada aspek permukaan tutupan, distribusi atau kepadatan, dan ketinggian atau kedalamn objek.

\section{Pertambangan Pasir dan Batu}

Dalam Undang-Undang Nomor 4 Tahun 2009 tentang Pertambangan Mineral dan Batubara Pasal 1 butir (1) disebutkan pertambangan adalah sebagian atau seluruh tahapan kegiatan dalam rangka penelitian, pengelolaan, dan pengusahaan mineral atau batu bara yang meliputi penyelidikan umum, eksplorasi, studi kelayakan, konstruksi, penambangan, pengolahan dan pemurnian, pengangkutan dan penjualan, serta kegiatan pasca tambang.

Undang-Undang Nomor 4 Tahun 2009 Usaha pertambangan adalah kegiatan dalam rangka pengusahaan mineral atau batubara yang meliputi tahapan kegiatan penyelidikan umum, eksplorasi, studi kelayakan, kostruksi, penambangan, pengolahan dan pemurnian, pengangkutan dan penjualan, serta pasca tambang.

Menurut Soedarmo dan Hadiyan (1981: 1) bahan galian adalah segala unsur kimia, mineral bijih dan segala macam batuan yang merupakan endapan alam, baik yang berbentuk padat, cair maupun gas. Terdapatnya endapanendapan bahan galian tersebut di dalam bumi bukanlah karena aktivitas manusia, binatang ataupun makhluk hidup yang 
lain. Terbentuknya endapan bahan galian memerlukan proses dan waktu yang lama akibat adanya proses geologi, differensiasi magma pada waktu menerobos lapisan kulit bumi, proses vulkanisme, pelapukan dan erosi, transportasi dan pengendapan kembali, dan dapat pula akibat proses metamorfosis. Penggolongan bahan galian terdiri dari tiga macam yaitu bahan galian A, B dan Golongan C. Penambangan pasir dan batu merupakan penambangan bahan galian Golongan C. Bahan ini merupakan bahan tambang yang tersebar di berbagai daerah yang ada di Indonesia.

\section{Sifat Tanah}

Tanah adalah suatu benda alami heterogen yang terdiri atas komponen-komponen padat, cair dan gas, dan mempunyai sifat serta perilaku yang dinamik. Benda alami ini terbentuk oleh hasil interaksi antara iklim dan jasad hidup terhadap bahan induk yang dipengaruhi oleh relief tempatnya terbentuk dan waktu (Arsyad, 2006). Tanah memiliki sifat-sifat kimia, biologi dan fisika.

Fisika tanah adalah penerapan konsep dan hukum-hukum fisika pada kontinum tanah-tanamanatmosfer. Sifat fisik tanah berperan penting dalam mendukung pertumbuhan tanaman. Sifat fisik tanah, seperti kerapatan isi dan kekuatan tanah sudah lama dikenal sebagai parameter utama dalam menilai keberhasilan teknik pengolahan tanah (Afandi, 2005). Sifat fisik tanah juga sangat mempengaruhi sifat-sifat tanah yang lain dalam hubungannya dengan kemampuannya untuk mendukung pertumbuhan tanaman dan kemampuan tanah untuk menyimpan air.

Sifat kimia tanah merupakan atribut tanah yang dapat digunakan untuk menilai apakah suatu tanah merupakan tanah yang potensial atau tidak (Hanafiah, 2005). Beberapa sifat kimia diantaranya $\mathrm{pH}$ tanah, karbon tanah, nitrogen, dan $\mathrm{C} / \mathrm{N}$ fosfat yang tersedia di tanah.

Bahan organik adalah semua bahan organik di dalam tanah baik yang mati maupun yang hidup, walaupun organisme hidup (biomassa tanah) hanya menyumbang kurang dari $5 \%$ dari total bahan organik. Jumlah dan sifat bahan organik sangat menentukan sifat biokimia, fisika, kesuburan tanah dan membantu menetapkan arah proses pembentukan tanah.

Sifat biologi tanah merupakan atribut keberadaan komponen biologis dalam tanah, diantaranya bahan organik dan unsur mikroba yang lain. Bahan organik menentukan komposisi dan mobilitas kation yang terjerap, warna tanah, keseimbangan panas, konsistensi, kerapatan partikel, kerapatan isi, sumber hara, pemantap agregat, karakteristik air, dan aktifitas organisme tanah (Mukhlis, 2007). 
Berbagai mikroba dan fauna tanah menjadi basis bagi konsep perlindungan dan penyehatan tanah, terutama pada masa kini dan mendatang dimana laju degradasi lahan terus mengancam sejalan denganmakin terbatasnya sumber daya lahan.

\section{METODE PENELITIAN}

\section{Lokasi Penelitian}

Penelitian dilakukan di Kali Gendol, Desa Kepuharjo Kecamatan Cangkringan Kabupaten Sleman DIY.

\section{Bahan Penelitian}

Penelitian ini menggunakan data primer berupa data hasil analisis sifat fisik, kimia, biologi tanah di lahan pasca penambangan pasir (sirtu).

Data sekunder yang digunakan meliputi:

- Data kondisi umum wilayah

- Arsip dan dokumentasi yang berkaitan dengan kegiatan pertambangan di lokasi pertambangan pasir (Sirtu).

- $\quad$ Peta lokasi tambang

\section{Teknik Pengambilan Sampel}

Metode pengambilan sampel tanah dialkukan secara Purposive Sampling dengan mengambil sampel tanah di bagian topsoil. Pengambilan sampel dilakukan pada setiap jenis penutup lahan sebanyak masing-masing tiga titik sampling.

\section{Teknik Pengolahan Data}

Sifat fisik, kimia dan biologi tanah diperoleh dengan uji laboratorium. Data hasil uji laboratorium kemudian diolah dengan menggunakan program SPSS.

\section{Teknik Analisis Data}

Analisis sidik ragam dengan uji T terhadap variabel yang diamati, dilakukan untuk mengetahui perubahan sifat fisik, kimia dan biologi tanah pasca kegiatan pertambangan pasir dan batu (Sirtu) pada variasi penutup lahan.Walaupun menggunakan individu yang sama, peneliti tetap memperoleh 2 macam data sampel, yaitu data dari perlakuan pertama dan data dari perlakuan kedua.

\section{HASIL DAN PEMBAHASAN}

\section{Hasil dan Analisis}

Desa Kepuharjo berada di kaki atau lereng Gunung Merapi dengan ketinggian 500-1000 meter diatas permukaan air laut. Kerusakan sumberdaya lahan yang terjadi akibat letusan Gunung Merapi adalah erupsi abu dan pasir yang menutupi lahan pertanian dan permukiman dengan ketebalan abu dan pasir yang bervariasi. Pasca erupsi, dilakukan penambangan material pasir secara besar-besaran. Saat ini, delapan tahun pasca erupsi Merapi Tahun 2010, material tersebut telah diambil dan menyisakan lahan-lahan yang luas yang dimanfaatkan oleh masyarakat sebagai lahan kebun. 
Sebagian dari lahan tersebut merupakan permukiman (sebelum erupsi), namun akibat dari awan panas sebagian permukiman di Desa Kepuharjo mengalami kerusakan dan tidak dapat dihuni.

Dari hasil pengamatan lapangan komoditas sayuran yang cepat beradaptasi adalah bawang daun. Sedangkan pada lahan pekarangan, jenis tanaman yang dapat menembus lapisan abu merapi adalah jenis umbi-umbian dan yang memiliki akar tinggal, seperti tanaman pisang dan talas. Pada lahan tegalan, tanaman yang cepat menyesuaikan diri adalah rumput pakan ternak yang biasa masyarakat setempat menyebutnya rumput kalanjana, karena untuk tumbuh rumput tersebut tidak banyak membutuhkan nutrisi terlalu banyak sehingga mudah tumbuh.Disamping itu, rumput pakan ternak dan tanaman pisang banyak dijumpai karena sudah beradaptasi pada lahan tersebut dan mudah ditemukan. Penanaman ini sekaligus dapat menjadi cara penanggulangan erosi dan aliran permukaan. Dengan kondisi sifat fisik tanah pasca erupsi merapi, menyebabkan lahan pertanian perlu pengolahan lahan yang teratur.

- Dari hasil pengamatan lapangan dan uji laboratorium diperoleh hasil analisis sifat fisik tanah dari sisi permeabilitas yang tidak menunjukkan perbedaan yang jelas pada setiap lapisan. Ini menunjukkan bahwa abu yang dilontarkan merapi dengan kadar air yang tinggi mampu meresap dan berpengaruh pada lapisan dibawahnya. Dari hasil pengamatan lapangan dan uji laboratorium diperoleh hasil analisis sifat fisik tanah dari sisi permeabilitas yang tidak menunjukkan perbedaan yang jelas pada setiap lapisan. Ini menunjukkan bahwa abu yang dilontarkan merapi dengan kadar air yang tinggi mampu meresap dan berpengaruh pada lapisan dibawahnya. Perbedaan sifat fisik tanah terjadi pada beberapa lokasi pengamatan, yaitu:

- Sifat Fisika Tanah: Tekstur tanah dominan adalah berupa tekstur tanah pasir.

- Sifat Kimia Tanah: Pada lokasi penutup lahan 1 yaitu di Hutan Sengon, terdapat nilai Sulfur (S) yang relatif tinggi (2183 dan 2201 ppm), sedangkan pada variasi penutup lahan Kebun Campur, nilai Sulfur (S) adalah pada nilai 239 dan 372 ppm. Pada umumnya $\mathrm{S}$ yang dibutuhkan untuk pertumbuhan optimal tanaman bervariasi antara 0.1 sampai $0.5 \%$ dari bobot kering tanaman (Marschner, 1995). Unsur S merupakan unsur makro yang dibutuhkan untuk pertumbuhan optimal tanaman, jika tanah kekurangan unsur $\mathrm{S}$ maka 
biasanya akan kekuranagn unsur makro lain seperti unsur $\mathrm{P}$ dan unsur $\mathrm{N}$.

- Sifat Biologi tanah, banyak terdapat cacing tanah di 3 land cover dengan kandungan Corganik diatas $5 \%$, yaitu Land cover rumput kalanjana dengan kadar rata-rata C-organiknya adalah 0,98, Hutan Sengon 1,475 dan kebun campur 0,935 . artinya bahwa kandungan C-Organik pada ketiga land cover tersebut adalah subur karena semua kandungan C-organiknya diatas $5 \%$.

Tabel 1.1. Variasi Penutup lahan dengan Perbedaan Sifak Kimia dan Biologi.

\begin{tabular}{|c|c|c|c|}
\hline $\begin{array}{l}\text { Variasi Penulup } \\
\text { Lahan } \\
\text { biologi-Kimia }\end{array}$ & $\begin{array}{l}\text { Hutan } \\
\text { Sengon }\end{array}$ & Kebun Campur & Rumput Ternak \\
\hline C-organik & 1.475 & 0.935 & 0.98 \\
\hline $\mathrm{N}$ & 0.145 & 0.065 & 0.07 \\
\hline k & 121 & 129.5 & 108.5 \\
\hline P205 & 33 & 32.5 & 38 \\
\hline $\mathrm{Fe}$ & 42 & 33 & 45.5 \\
\hline s & 2192 & 305.5 & 1477 \\
\hline
\end{tabular}

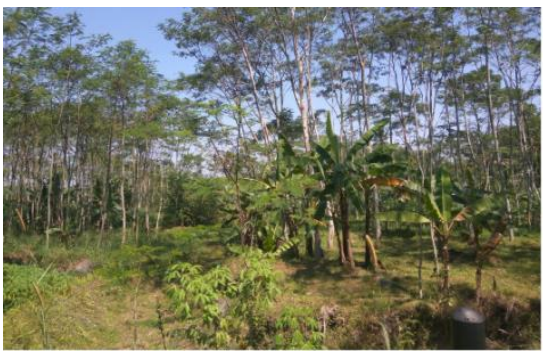

Gambar 1.1. Tutupan Lahan Hutan Sengon

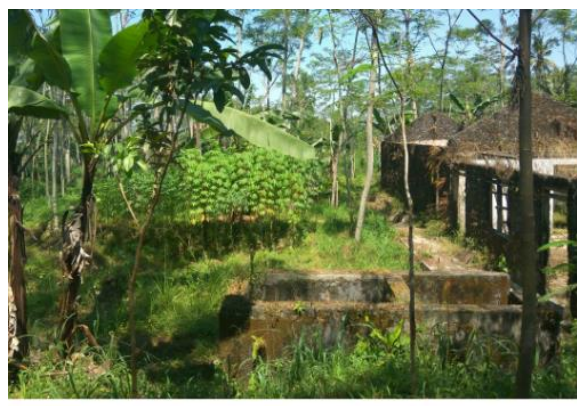

Gambar 1.2. Tutupan Lahan Kebun Campur.

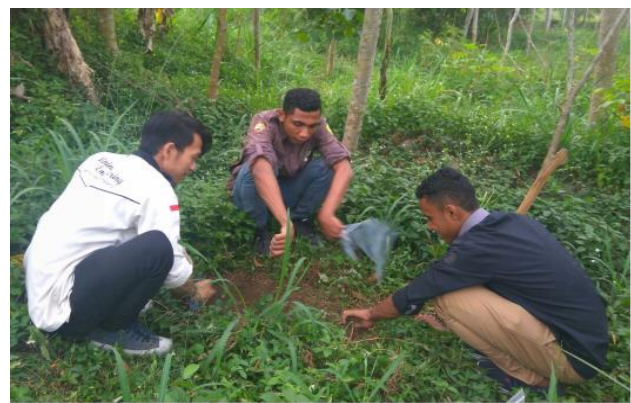

Gambar 1.3. Tutupan Lahan Rumput Ternak

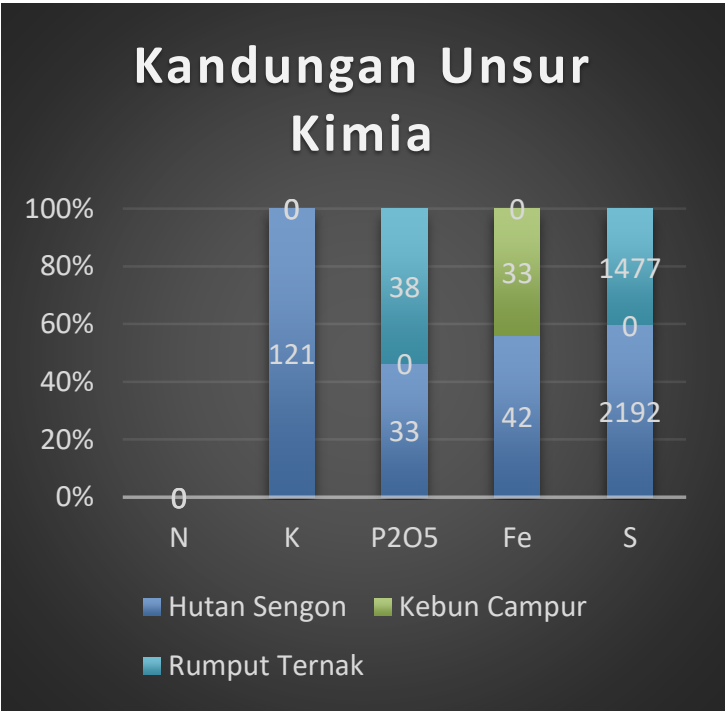

Gambar 1.4. Kandungan Unsur Kimia Pada ketiga Penutup Lahan 


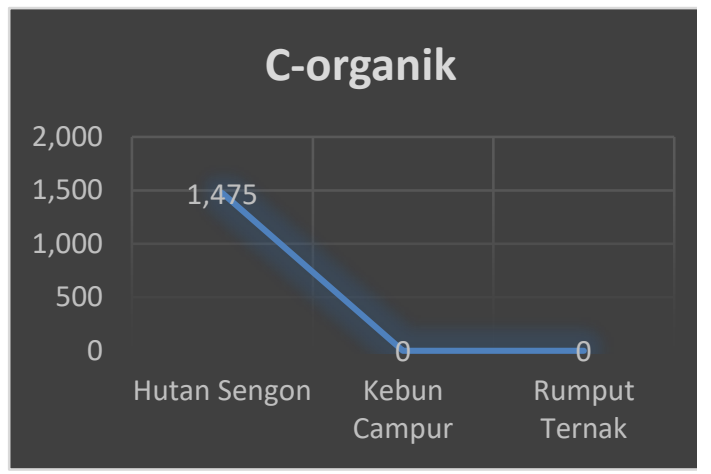

Gambar 1.5. Kandungan C-Organik Pada ketiga Penutup Lahan

\section{KESIMPULAN}

\section{Kesimpulan}

Berdasarkan hasil analisis sementara, diperoleh kesimpulan sebagai berikut:

a. Dominasi variasi penutup lahan di Desa Kepuharjo, Kecamatan Cangkringan adalah Kebun Campur, Hutan Sengon, dan Tegalan Rumput Gajah.

Sifat Fisika Tanah: Tekstur tanah dominan adalah berupa tekstur tanah pasir.

Sifat Kimia Tanah: Pada lokasi penutup lahan 1 yaitu di Hutan

Sengon, terdapat nilai Sulfur (S) yang relatif tinggi (2183 dan 2201 ppm), sedangkan pada variasi penutup lahan Kebun Campur, nilai Sulfur (S) adalah pada nilai 239 dan 372 ppm. Pada umumnya S yang dibutuhkan untuk pertumbuhan optimal tanaman bervariasi antara 0.1 sampai $0.5 \%$ dari bobot kering tanaman (Marschner, 1995). Unsur S merupakan unsur makro yang dibutuhkan untuk pertumbuhan optimal tanaman, jika tanah kekurangan unsur S maka biasanya akan kekuranagn unsur makro lain seperti unsur $\mathrm{P}$ dan unsur $\mathrm{N}$.

Sifat Biologi tanah, terdapat cacing tanah di 3 land cover dengan kandungan C-organik diatas 5\%, yaitu Land cover rumput kalanjana dengan kadar rata-rata C-organiknya adalah 0,98, Hutan Sengon 1,475 dan kebun campur 0,935. artinya bahwa kandungan C-Organik pada ketiga land cover tersebut adalah subur karena semua kandungan Corganiknya diatas $5 \%$.

\section{Saran}

Untuk menjaga kondisi tanah dan tanaman yang cocok maka perlu variasi jenis tanaman dalam penanaman selain sengon, seperti tanaman keras yang bernilai ekonomi lainnya.

\section{DAFTAR PUSTAKA}

Afandi. 2005. Fisika Tanah I. Jurusan Ilmu Tanah, Fakultas Pertanian. Universitas Lampung. Bandar Lampung.

ArsyadS., 2006.Konservasi Tanah dan Air. IPB Press, Bogor.

BSN, 2010. Klasifikasi Penutup Lahan. SNI 7645. Jakarta.

Hanafiah, K.A, 2005. Dasar-Dasar Ilmu Tanah. Jakarta : PT. RajaGrafindo Persada. 
http://ebook.repo.mercubuana-

yogya.ac.id/Kuliah/materi_20

151_doc/e-

learning\%20uji\%20beda\%20r

ata-rata\%201.pdf

Kuswandi, 1993. Pengapuran Tanah

Pertanian. Yogyakarta :

Kanisius.

Marschner, H. 1995. Mineral Nutrion of Higher Plants. 2 nd ed. Academic

Press. London

Mukhlis, 2007.Analisis Tanah dan

Tanaman. USU press, Medan.

Saraswati,R, dkk. 2007. Metode Analisis Biologi Tanah. Balai Besar Litbang Sumberdaya

Lahan Pertanian. Badan

Penelitian dan Pengembangan

Pertanian Departemen

Pertanian.

Soedarmo dan Hadiyan, 1981.

Petunjuk Praktek Bahan

Galian. Jakarta : Depdikbud

Utami Nur Hikmah, 2009. Kajian

Sifat Fisik, Sifat Kimia Dan

Sifat Biologi Tanah Paska

Tambang Sirtu Pada Tiga

Penutupan Lahan (Studi Kasus

Pertambangan Pasir (Sirtu) Di

Desa Gumulung Tonggoh,

Kecamatan Astanajapura,

Kabupaten Cirebon, Provinsi

Jawa Barat). Departemen

Silvikultur, Fakultas Kehutanan

Institut Pertanian Bogor.

Yudhistira, 2008. Kajian Dampak

Kerusakan Lingkungan Akibat
Kegiatan Penambangan Pasir di Daerah Kawasan Gunung Merapi (Studi Kasus di Desa Keningar, Kecamatan Dukun, Kabupaten Magelang, Provinsi Jawa Tengah). Tesis. Universitas Diponegoro. 
